\title{
Development of the Elderly's Resources Against the Perspective of Active Aging
}

\author{
Yanni Li \\ School of Public Affairs \& Law \\ Southwest Jiaotong University \\ Chengdu, China
}

\begin{abstract}
In the past, scholars regarded the elderly population as the burden of society. As the social rights of the elderly were valued, scholars believed that the elderly could also create social wealth and put forward the idea of active aging. Against the background of China's aging population problem, the development of the elderly's resources is getting more and more attention from scholars. This article starts from the development of China's elderly resources and combines active aging with the development of the elderly's resources. The positive effect and the sustainability of pensions explains the significance of the development of the elderly's resources, drawing on the experience of other countries, to improve the level of human resources development in China, ease the pressure of pensions in China, and fully play the role of the elderly.
\end{abstract}

Keywords-active aging; human resources management of the elderly; post-retirement employment; pension

\section{INTRODUCTION}

With the advancement of medical and health technology, the prolongation of life expectancy and the growing problem of population aging are becoming more and more concerned. Internationally, the proportion of the population aged 60 and over to the total population is $10 \%$ as the standard for a country or region to enter an aging society. China has entered the ranks of aging countries around 2000. In recent years, the proportion of people over 60 years old has reached $17.3 \%$. The problem of population aging in China has been very serious, with the characteristics of "not getting rich first" and regional imbalances. Guiding the elderly people in China to actively participate in labor is not only a manifestation of the concept of active aging, but also a very important aspect of China's current "six old" policies. The aging of the population has brought tremendous pressure on pensions. The development and utilization of the resources of the elderly is of great significance for relieving pension pressure and reducing the negative impact of population aging.

\section{The Status QUO OF THE ELDERLY RESOURCES IN CHINA}

The resources of the elderly in China show the basic characteristics of "poor quality and quantity" in the eastern coastal areas and "poor quality" in the inland areas of the central and western regions. The employed elderly are mainly concentrated in low-end labor-intensive industries and relatively high-end knowledge-intensive industries. The former is mainly for survival employment, while the latter is mostly value-based employment. Most of the elderly are directly employed and informal employment.

According to the 2010 China Urban Age Science Research Center's tracking of the situation of urban and rural elderly population in China, $0.5 \%$ of the urban elderly in China are still working, and the number of people reemployed (including re-employment) accounts for $7.2 \%$. In the rural areas, $44.3 \%$ of the elderly are still working in agriculture, and the elderly who work and do business account for $8.6 \%$. In 2014, the number of rural elderly in China who engaged in occupational labor (such as farming) reached $54.6 \%$. A large number of studies have shown that the development of the resources of the elderly in China's urban and rural areas is very different. In China's rural areas, about $51.35 \%$ of the elderly's resources are mainly based on labor income, while the towns are only $18.5 \%$. The employment rate of urban elderly is low, and the employment after retirement is mainly to achieve self-worth; the employment rate of rural elderly is higher, mainly for survival, and the employment for whatever purpose has a positive effect on the use and development of the resources of the elderly.

\section{ACTIVE AGING}

\section{A. From Healthy Aging to Active Aging}

In the 1980s, the "health aging" proposed by scholars focused on the physical and mental needs of the elderly, and did not pay attention to the social rights of the elderly, mainly to maintain the basic health of the elderly and improve the quality of life of the elderly. With the attention of the social rights of the elderly, in the late 1990s, scholars put forward the concept of "active aging", which not only paid attention to the health and life security of the elderly, but also concerned the social participation of the elderly. "Active aging" no longer regards the elderly as the burden of society, but regards the elderly as the creators of social wealth and contributors to social progress. In addition, countries actively promote "live to the old and be old" and the concept of "active aging." 


\section{B. Active Aging and Management of the Elderly's Resources}

Under the guidance of this concept, scholars began to pay attention to the development and utilization of the resources of the elderly. Sauvy (1948) and Coale (1976) pointed out in the policy recommendations on the study of population aging, that the active development of the resources of the elderly can be a very important means and method to deal with the aging of the population. Donald (1993) also demonstrated the role of the development of the elderly in the context of labor shortages. AARP (1995) studied the impact of the development of the elderly on public resources such as pensions, and believed that the development of the elderly is conducive to the sustainable development of the entire social pension and other public resources. Morrow-Howell and Sherraden (2011) have shown that the development of older people has a positive impact on the elderly themselves and the community. Dostie (2011), Hakes and Turner (2011) studied the productivity problems of the elderly and confirmed that older people are as productive as young people and are worth developing. Data surveys by Moneer Alam and Arup Mitra (2012) show that older people participate in market labor and have a positive impact on their health.

\section{THE SignifiCANCE OF THE DEVELOPMENT OF THE ELDERLY'S RESOURCES}

\section{A. Positive Role of Retirement and Rehiring}

According to scholars' research, retirement will lead to a decrease in individual life satisfaction, and retirement rehiring will positively affect the physical and mental health of retirees. Dingemans and Henkens (2014) suggest that although retirement will bring more freedom, the loss of individuals in economic and social resources will lead to a decline in self-worth. Kim and Feldman (2000) found that retirement repatriation has a positive impact on the retirement satisfaction and life satisfaction of older employees. They found that employees who returned to the original unit had higher satisfaction with the life of the employees who returned to the outside unit. A study by scholar Wang (2007) found that retirement rehiring helps retirees maintain their psychological well-being in retirement. Scholar Zhan (2009) uses continuing theory and role theory to find that retired retirees are less likely to be ill or have dysfunction, and engaging in career resignation has a significant positive impact on the mental health of retired employees. Retirement and rehiring not only improve the life satisfaction of the elderly, but also have a positive effect on the health of the elderly.

\section{B. Pension Sustainability}

The three problems in China's pensions are: insufficient pension reserves; pension expenditures continue to increase; the pension gap continues to expand. This has caused the continued shortage of pensions in China, and the aging of the population has intensified the lack of pension capacity. Some researchers at the Director of the World Social Security Research Center of the Chinese Academy of Social Sciences predicted that the retirement age of our employees was postponed for one year, and the pension fund could grow by 4 billion yuan and reduce the deficit by 16 billion yuan. Reasonable development of the resources of the elderly, extension of the retirement age, and implementation of a flexible retirement system are of great significance to alleviate the current excessive pressure on pensions in China. On the one hand, the elderly participate in employment, the number of people who continue to pay pensions increases, and the income of pensions expands; on the other hand, the amount of pension is relatively reduced, pension expenditure scale is reduced, pension balance is increased, and pension pressure is reduced, so as to realize the sustainability of China's pension.

\section{ReleVAnt Policies of VARIOUs Countries}

\section{A. Flexible Retirement System}

Throughout the ageing countries, such as Germany, South Korea, and Japan, the retirement age has been delayed. After employees reach a certain age, they can choose to continue their work, reduce working hours, or retire. Retirement is linked to pensions. Early retirement will result in a reduction in pensions and subsidies for the elderly who continue to work. The minimum working hours per week for senior employees is stipulated in the form of a decree. Employees are free to arrange daily working hours. China's law stipulates that the retirement age is smaller than other countries with severe aging. The Third Plenary Session of the 18th Central Committee of the Communist Party of China (the Central Committee of the Communist Party of China's decision on comprehensively deepening the reform of major issues) clearly states that it is necessary to study the policy of establishing a progressive postponement retirement system. The Ministry of Human Resources and Social Security mentioned that the legalization of postponement of retirement reform plays an important role in promoting the development of human resources for the elderly.

\section{B. American Tenure System}

The tenure system in the United States means that an associate professor or professor who has obtained a tenure can be excused from being dismissed for no reason. Even at the age of retirement, he can continue to teach or engage in scientific research at his own will, if there is no special reason, regardless of the school or the board of directors. They have no right to dismiss them. Faculty members who have tenured faculty must strictly abide by the rules and guidelines of the 1940 Declaration. Once violations are discovered, tenure will be disqualified. In the end, many colleges and universities in the United States have established a tenure system to reduce and stop research after many professors have obtained tenure qualifications, and reward professors with rich scientific research results. The lifelong non-retirement system of Chinese academicians is a good practice for the development of the elderly's resources. 


\section{Japan Silver Talent Center}

The Japan Silver Talent Center aims to improve the quality of life of the elderly by providing suitable employment opportunities for the elderly. It is a public and public welfare organization with a semi-official and a halfminded people. The institution is not for profit, its financial losses are subsidized by the government, and elderly people over the age of 60 who are healthy and have the desire to work again can apply for membership. The central and local silver talent centers perform their duties, and the central government coordinates and guides the local silver talent center to play a role. The local silver talent center not only provides employment information for the elderly, but also recommends suitable candidates for the enterprise and vocational skills training for the elderly. This helps the elderly to find employment. China has not yet established relevant institutions to help the elderly to find employment.

\section{German Vocational Training Program}

In the Internet age, technology is changing with each passing day. The ability of older workers to master new knowledge and new equipment is limited. Their knowledge and skills are relatively old, and sometimes they cannot be integrated into new production activities. This will not only reduce the labor productivity of enterprises that employ older people, but also make it difficult for the elderly unemployed to find new jobs. In response to this situation, the German government has introduced policies to improve the labor skills of older workers. The German vocational training program covers a wide range of short-term plans, as well as medium- and long-term plans, to acquire professional knowledge and skills through training individuals. In addition, they offer opportunities for career development or career change as well as professional qualifications. China has not established a vocational training program for the elderly.

\section{E. Korean 50-60 Year Old Work Club}

In accordance with the company, the type of job, the region, etc., and using public places such as employment centers, self-governing organizations, and public agencies, Korean government promotes the establishment of a place for 50-60 year old retirees to interact with each other. In 2012, the Korean government promoted 50-60 year old work club in the country. The services provided by the venue mainly include emotional bursts, entrepreneurship and job information. The club's setting not only provides a place for the elderly to communicate with each other, but also helps to understand the employment needs of the elderly, employment barriers, and provide advice and reference for the improvement of policies. China has not yet established a place for the exchange of work for the elderly.

\section{CONCLUSION}

The increase in the elderly population has put pressure on China's pensions, the rise in the old-age dependency ratio, and the decline in China's demographic dividend, which has forced us to use the resources of the elderly. Older people continue to participate in the work, not only can ease the pressure of pensions, but also promote their physical and mental health. China should learn from the experience of other countries and create an environment conducive to the employment of the elderly. First of all, it is possible to extend the retirement age and establish a flexible retirement system. Older people of a certain age can choose to work or retire independently. Secondly, improve the system of nonretirement for academicians and encourage them to carry out technological innovation. Third, establish an institution to help the elderly to find employment, provide relevant employment information to the elderly, and provide vocational training to the elderly who need it. Fourth, establish a place for the elderly to interact with each other and provide a place to express emotions and exchange work information.

\section{REFERENCES}

[1] Hu Cangping, Du Peng. Aging Society and Harmonious Society [M] Beijing: China Population Publishing House, 2012:5.

[2] Mao Jianru. Human Resource Development [J]. Journal of Hebei Normal University: Educational Science Edition, 2017:85.

[3] China Center for Aging Science. Rural pension status report: more than half of rural elderly are still working [N]. First Financial Daily, 2015-06-08.

[4] Peng Du, Promoting healthy aging — conceptual change and Policy Innovation: an interpretation of the WHO's global report on aging and health. Aging Research, 2015(12).

[5] Alfred Sauvy. Social and Economic Consequences of the Aging of Western European Countries [J]. Population Studies, 1948 (2): 152 183.

[6] Ansley J. Coale. Economic Factors in Population Growth [M]. NY: Jone Wiley \& Sons, 1976: 1-44

[7] AARP. American business and older workers [R],1995:1-22

[8] Morrow-Howell, N., Hingterlong, J., Sherraden, M. Productive aging: concepts and challengs [M]. Baltimore: John Hopkins University Press, 2011: 1-19.

[9] Moneer Alam, Arup Mitra. Labor market vulnerabilities and health outcomes: older workers in India [J]. Population Ageing, 2012(5): 241-256.

[10] Adamchak Donald J. Demographic aging in the industrialized world a rising burden?. Generations, 1993, 17:6-9.

[11] Benoit Dostie. Wages, productivity and aging [J]. De Economist, 2011,159: 139-158.

[12] Jahn K. Hakes, Chad Turner. Pay, productivity and aging in major league baseball [J]. J Prod Anal,2011, 35: 61-74.

[13] Dingemans E, Henkens K. Involuntary retirement, bridge employment, and satisfaction with life: A longitudinal investigation. Journal of Organizational Behavior, 2014,35(4): 575-591.

[14] Kim S, Feldman D C. Working in retirement: The antecedents of bridge employment and its consequences for quality of life in retirement. Academy of Management Journal, 2000,43(6):1195-1210.

[15] Wang M. Profiling retirees in the retirement transition and adjustment process: Examining the longitudinal change patterns of retirees' psychological well-being. Journal of Applied Psychology, 2007,92(2) 455-474.

[16] Zhan Y, Wang M, Liu S, et al. Bridge employment and retirees' health: A longitudinal investigation [J]. Journal of Occupational Health Psychology, 2009,14(4): 374-389.

[17] Qingcai Wu, Decision of the Central Committee of the Communist Party of China on several major issues of comprehensive deepening reform. Ideological and moral education, 2014(3): P28-28.

[18] Dendinger V M, Adams G A, Jacobson J D. Reasons for working and their relationship to retirement attitudes, job satisfaction and 
occupational self-efficacy of bridge employees. International Journal of Aging and Human Development, 2005, 61(1):21-35.

[19] Association's stuff. Academic Freedom and Tenure: University of Central Arkansas [R]. ACADEME, 2000-03/04.

[20] Japan International Longevity Center: http://longevity.ilcjapan.org/f_issues/0702.html

[21] Li Huizhu.Zeng Xiumei. Research on South Korea's support measures for minority children [J]. Journal of Korean Institute, 2014(25):47-80. 